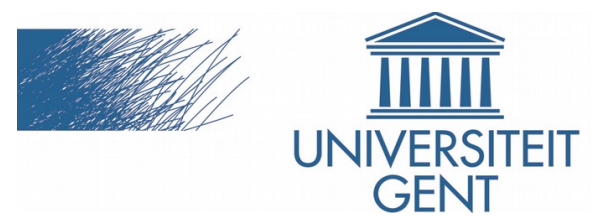

biblio.ugent.be

The UGent Institutional Repository is the electronic archiving and dissemination platform for all UGent research publications. Ghent University has implemented a mandate stipulating that all academic publications of UGent researchers should be deposited and archived in this repository. Except for items where current copyright restrictions apply, these papers are available in Open Access.

This item is the archived peer-reviewed author-version of:

Phosphorus retention capacity in red ferralitic soil

Pérez, M. M., J. Bossens, E. Rosa, and F. M. G. Tack

In: Water Science \& Technology 70 (9), 1561-68, 2014.

http://www.iwaponline.com/wst/07009/wst070091561.htm

To refer to or to cite this work, please use the citation to the published version:

Pérez, M. M., J. Bossens, E. Rosa, and F. M. G. Tack (2014).

Phosphorus retention capacity in red ferralitic soil. Water Science \& Technology(70) 1561-1568. doi:10.2166/wst.2014.410 


\title{
PHOSPHORUS RETENTION CAPACITY IN RED FERRALITIC SOIL
}

\author{
M. M. Pérez ${ }^{\mathrm{a}}$, J. Bossens ${ }^{\mathrm{b}}$, E. Rosa ${ }^{\mathrm{a}}$, F.M.G. Tack ${ }^{\mathrm{b}}$ \\ ${ }^{a}$ Study Center of Applied Chemistry. Chemical Pharmacy Faculty. Central University of Las Villas. Cuba \\ ${ }^{\mathrm{b}}$ Department of Applied Analytical and Physical Chemistry, Bioscience Engineering Faculty, Ghent \\ University, Belgium.
}

\begin{abstract}
In this study the main physical-chemical characteristics in the red ferralitic soil to use as substrate in subsurface wetlands was determined. The P-removal was evaluated in a short-term isotherm batch experiment and in a column percolation experiment. The acid characteristic and high content of iron minerals in the red ferralitic soil facilitated the phosphorus removal. Also the sorption isotherms at two different temperatures were obtained. The results showed that the sorption capacity increases with an increase in solution temperature from $25^{\circ} \mathrm{C}$ to $35^{\circ} \mathrm{C}$. The experimental data was fitted to Langmuir and Freundlich models, having a better fit to the Freundlich isotherms. The maximum P-sorption capacities estimated using the Langmuir-isotherm were $0.96-1.13 \mathrm{~g} / \mathrm{kg}$ at 25 and $35{ }^{\circ} \mathrm{C}$ respectively. Moreover a column experiment was carried out at two different flows. Sequential extractions of the phosphorus saturated soil indicated that phosphorus is mainly bound with iron or aluminium minerals. The results have demonstrated a good potentiality for red ferralitic soil for phosphorus removal from urban wastewater.
\end{abstract}

Keywords: phosphorus removal, subsurface wetlands, sorption isotherms 


\section{INTRODUCTION}

Subsurface flow constructed wetlands gained in popularity as efficient and economical treatment alternative. Wastewater treatment is achieved in a constructed wetland through an integrated combination of biological, physical and chemical interactions among plants, substrate and microorganisms (De Feo, 2007). Due to the minimum requirement for their operation and management, constructed wetlands are promoted as low-cost technology for the treatment of both municipal and industrial wastewater.

Generally, subsurface wetlands present a good performance in the removal of main pollutants. However, phosphorus removal has not been effective, being obtained removal efficiencies between $20-30 \%$. Hence the importance of consider complexity of phosphorus removal mechanisms in the design of these treatment systems (Kadlec and Knight, 1996).

Phosphorus removal in wetlands may take place due to plant uptake, accretions of wetland soils, microbial immobilization, retention by the substrate and precipitation in the water column. Among these factors, the substrate may play the greatest role and could be the factor most amenable to control (Ayoub et al., 2001), (Brix et al., 2001). Consequently, it is important to select those substrates presenting the highest phosphate adsorption capacity, which depends mainly on the specific physical-chemical properties of these materials, including $\mathrm{pH}$, redox potential, dissolved ions and minerals content (Vohla, et al., 2011).

The ability of substrate for phosphorus retention is attributed to content of iron aluminium, and calcium in the same one, because the phosphorus is removed by sorption and precipitation processes (Vohla, et al., 2011); (Klimeskiet et al. 2012). In substrates with high iron and aluminum contents, at $\mathrm{pH}$ lower than 6 , are favoured precipitation processes, whereas at higher $\mathrm{pH}$ values are favoured the physical adsorption processes (Zhu et al., 2003). The most oxidized conditions also tend to favour phosphorus removal in subsurface wetlands. Phosphorus sorption efficiencies of many substrates have been examined including: gravel, dolomite, furnace slag, fly ash, shale, limestone, and sand amont other. Many studies carried out with natural products (Arias, 2001); (Sikdar 2007); (Gustafsson, 2008), and the other studies were based on man-made products and industrial by-products (Zhu et al., 2003); (Xu et al., 2006); (Adam et al., 2007) and (Gustafsson, 2008).

In previous studies, phosphorus removal using different substrates and sediments proved to be an endothermic process and higher temperature was preferred for the removal of phosphorus (Huang, 2011); (Jin, 2005); (Mezenner, 2009); (Herrmann et al., 2014). The adsorption of phosphorus may involve not only physical but also chemical sorption processes and the particular processes that take place depend on the composition of the substrate used.

Pérez, (2009) evaluated several substrate in vertical subsurface wetlands at laboratory level and obtained good results in the phosphorus removal with the use of red ferralitic soil as substrate. This soil has an elevated minerals composition so it can be an attractive substrate to use as subsurface wetlands substrate and is naturally available in different regions of Cuba.

The present work has as aim to evaluate the P- removal capacities at two temperature of red ferralitic soil for use as substrate in subsurface wetlands and to identify the main removal mechanisms to phosphorus. 


\section{MATERIALS AND METHODS}

\section{Red ferralitic soil characterization}

The soil used in this study was obtained in Mata, Cifuéntes, Villa Clara, in the central region of Cuba. P-removal properties of this soil were evaluated and hence their applicability for use as subsurface constructed wetlands substrate. The porosity was determined using the standard soil science procedure based on estimations of bulk density and particle density (Klute, 1986). Following physical-chemical soil parameters were determined according to Van Ranst (2005), pH$\mathrm{KCl}, \mathrm{pH}-\mathrm{H}_{2} \mathrm{O}$ and electrical conductivity by electrometric methods, organic matter was determined by gravimetric method and total carbonate by volumetric method. The total phosphorus was measured according to colorimetric method of Sheel. Total nitrogen and ammonium nitrogen were determined by Kjeldahl method. Cation exchange capacity was determined according to the continue extraction methods and finally the metals were analysed by plasma optical emission spectroscopy.

\section{Kinetic experiment}

A kinetic experiment was carried out by contacting $5 \mathrm{~g}$ of red ferralitic soil, placed in a $200 \mathrm{~mL}$ Erlenmeyer flask, with $150 \mathrm{ml}$ of standard solution of $\mathrm{KH}_{2} \mathrm{PO}_{4}$ with a concentration of $8 \mathrm{mg} \mathrm{P} / 1$. This concentration is in the order of that in typical urban wastewaters. To minimize splashing and evaporation, all Erlenmeyer flask were covered with plastic film. Measurement was performed at different times $(0.5,1,1.5,2,2.5,3.3 .5,4,4.5,5 \mathrm{~h})$. The solutions were continuously agitated using magnetic stirrer (Heidolph MR Hei-Tec, Germany) with temperature control. Initial $\mathrm{pH}$ of solution was adjusted to the required value $(\mathrm{pH} 7)$ with diluted $\mathrm{NaOH}$ solutions. Duplicate analyses were conducted for each experiment. Samples were filtered using Whatman polyamide membrane filters $(0.45 \mu \mathrm{m})$ in order to obtained e clarify solution for phosphorus determination. The phosphorus concentration was determined according to Standard Methods (ALPHA, 2000) using the ammonium molybdate method. All procedure described above was repeated for two different temperatures $\left(25^{\circ} \mathrm{C}\right.$ and $\left.35^{\circ} \mathrm{C}\right)$ and with urban wastewater, whose properties are shown in Table 1.

The experimental data phosphorus removal was fitted to the different kinetic models. The integrated form of the rate expression for zero order and second order are gives by equations 1 and 2 .

$C_{\text {in }}-C_{\text {out }}=-k t$

$k t=\frac{1}{c_{\text {out }}}-\frac{1}{c_{\text {in }}}$

Where $\mathrm{k}$ is a reaction rate constant $\left(\mathrm{mg} \mathrm{L}^{-1} \mathrm{~d}^{-1}\right), \mathrm{C}_{\text {in }}$ is an influent concentration $(\mathrm{mg} / \mathrm{L})$ and $\mathrm{C}_{\text {out }}$ effluent concentration $(\mathrm{mg} / \mathrm{L})$.

First-order degradation represents the basic kinetic model for these systems; it is expressed by equation 3.

$\ln \frac{C_{\text {out }}}{c_{\text {in }}}=-k t$

Where $\mathrm{k}$ is a reaction rate constant $\left(\mathrm{d}^{-1}\right)$

Equation 4 represents the Monod model (Metcalf and Eddy, 2003).

$k t=K \cdot \ln \frac{C_{\text {in }}}{C_{\text {out }}}+\left(C_{\text {in }}-C_{\text {out }}\right)$

Where $\mathrm{k}$ is a reaction rate constant $\left(\mathrm{mg} \mathrm{L}^{-1} \mathrm{~d}^{-1}\right)$ and $\mathrm{K}$ is a damping factor $(\mathrm{mg} / \mathrm{L})$ 


\section{Sorption isotherm experiments}

Equilibrium experiments were performed with the red ferralitic soil to determine sorption isoterms. Five $\mathrm{g}$ of soil was placed in 200-mL Erlenmeyer flask and $150 \mathrm{~mL}$ of standard solution of $\mathrm{KH}_{2} \mathrm{PO}_{4}$ to give 8 levels of phosphorus $(0,2.5,5,10,20,40,80$ and $120 \mathrm{mgP} / \mathrm{L})$ were then added. The Erlenmeyer were sealed and were continuously agitated in a magnetic stirrer (Heidolph MR HeiTec, Germany) with temperature control; at two different temperatures $\left(25^{\circ} \mathrm{C}\right.$ and $\left.35^{\circ} \mathrm{C}\right)$ for $8 \mathrm{~h}$. Blanks containing no soil were always included in the experiments. The samples were filtered using Whatman polyamide membrane filters $(0.45 \mu \mathrm{m})$ and the concentration of $\mathrm{P}$ in the filtrate was measured according to Standard Methods (ALPHA, 2000) using ammonium molybdate method. The amount of phosphorus removed from solution by the soil was calculated from the decrease in $\mathrm{P}$ concentration in the solution. The apparent P-sorption capacity of the soil was estimated using the linear form of the Langmuir equation.

$$
\frac{C e}{q}=\frac{C e}{q \max }+\frac{1}{q \max } \times b
$$

Where

Ce: concentration of $\mathrm{P}$ in solution at equilibrium $(\mathrm{mg} / \mathrm{L})$

$\mathrm{q}$ : mass of $\mathrm{P}$ adsorbed to the soil $(\mathrm{g} / \mathrm{kg})$

$\mathrm{q}_{\text {max }}$ : apparent P-sorption capacity $(\mathrm{g} / \mathrm{kg})$

$\mathrm{b}$ : constant related to the binding strength of $\mathrm{P}$

The Freundlich isotherm was derived empirically and refers to a sorption model where the affinity term decreases exponentially as the sorption amount increases. It also incorporates the heterogeneity of the surface and the distribution of adsorption sites and their energies. It is possible to determine the constants in the following Freundlich isotherm by log-transforming the equation.

$$
\ln q=\frac{1}{n} * \ln C e+\ln k
$$

Where

Ce: concentration of $\mathrm{P}$ in solution at equilibrium $(\mathrm{mg} / \mathrm{L})$

q: mass of $\mathrm{P}$ adsorbed to the soil $(\mathrm{g} / \mathrm{kg})$

n: Freundlich intensity parameter, change according to heterogenic grade.

$\mathrm{k}$ : Freundlich capacity factor $(\mathrm{L} / \mathrm{g})$, related to affined between solvent and solvate.

To determine the best fit of the collected isotherm data, both the Langmuir and Freundlich isotherm models were fitted to each of the experimental data sets. For the Langmuir model, this was accomplished by plotting [Ce/q] versus $C e$ and then fitting a linear regression line to the data using Excel Software (Microsoft Corporation, 2007). The appropriateness of the Langmuir isotherm was assessed by determining the $\mathrm{R}^{2}$ values (coefficient of determination) of the linear regression lines. Similarly, for the Freundlich model, ln (q) was plotted against $\ln C e$ and a linear regression line was fitted. As described previously, it was possible to determine the effectiveness of the model based on the correlation coefficient $\left(\mathrm{R}^{2}\right)$ value of the modelled results.

\section{Column experiment}

Two experimental columns (diameter $40 \mathrm{~mm}$ ) were packed with $200 \mathrm{~g}$ of red ferralitic soil. Water spiked with $\mathrm{KH}_{2} \mathrm{PO}_{4}$ to a $\mathrm{P}$ concentration of $8 \mathrm{mg} / \mathrm{L}$ ( $\mathrm{pH}$ adjusted to 7.2 with $\mathrm{NaOH}$ ) was supplied continuously at two different flows $0.03 \mathrm{~L} / \mathrm{h}$ and $0.06 \mathrm{~L} / \mathrm{h}$ using a feeding tank. The two flow rates correspond to a nominal retention time of $4.5 \mathrm{~h}$ and $2.3 \mathrm{~h}$, respectively. The effluent from each column was collected at different time $(0.5,1,2,3,4,6,8,32,56,80,104,128,152,176$ and 200 $\mathrm{h}$ respectively). The $\mathrm{P}$ concentration was analyzed as described above. Furthermore, $\mathrm{pH}$ and electric conductivity were measured. 


\section{Sequential extraction}

After approximately 8 days of continuous loading the column experiment was concluded. In order to elucidate the main bound of the phosphorus in the soil and the main mineral that intervene in the phosphorus adsorption, a sequential extraction scheme was performed on the soil used in the columns, following a protocol of Hieltjes and Lijklema (1980). The fractionation scheme include (1) two consecutive extractions in $1 \mathrm{~mol} / \mathrm{L} \mathrm{NH}{ }_{4} \mathrm{Cl}$ at $\mathrm{pH} 7$ (denoted adsorbed-P), (2) two consecutive extractions in $0.1 \mathrm{~mol} / \mathrm{L} \mathrm{NaOH}$ followed by extraction in $1 \mathrm{~mol} / \mathrm{L} \mathrm{NaCl}$ (denoted $\mathrm{Fe}+\mathrm{Al}$ bound-P), (3) extraction in $0.5 \mathrm{~mol} / \mathrm{L} \mathrm{HCl}$ (denoted $\mathrm{Ca}+\mathrm{Mg}$ bound- $\mathrm{P}$ ), and (4) analysis of the remaining $\mathrm{P}$ in the soil after ignition at $550{ }^{\circ} \mathrm{C}$ and extraction in boiling $1 \mathrm{~mol} / \mathrm{L} \mathrm{HCl}$ (denoted residual-P). Analyses were performed in duplicate for each column.

\section{Statistical analysis}

One-way ANOVA with 95\% the significance criterion was performed using Statgraphics centurion software XV.II to determine if significant differences exist between the phosphorus concentration at two temperatures in the kinetic and sorption experiment and between the wastewater and standard solution in the kinetic experiment.

\section{RESULTS AND DISCUSSION Characterics of the red ferralitic soil}

The acids characteristic and high iron content of red ferralitic soil make it suitable for use as substrates in subsurface constructed wetlands systems. The main phosphorus removal mechanisms take place by means of the reactions of the minerals contained in the soil with phosphorus presented in the wastewater. When the soil has acid characteristic, the minerals that have more influences in phosphorus removal are the iron or aluminium. The main chemical-physical characteristics of this soil are presented in Table 2 and 3.

\section{Kinetic model of phosphorus removal}

Fig. 1 shows the kinetic behaviour of phosphorus removal with red ferralitic soil. The maximum phosphorus adsorption was obtained at 3.5 hour in all the case. Also it is observed that at $35^{\circ} \mathrm{C}$ the adsorption began faster than $25^{\circ} \mathrm{C}$.

Table 4 shows the line equation and the correlation coefficient for the four models studied. In all cases the experiment data fits to the second order model. According what's reported in the literature, phosphorus removal does not follow a first order model, which is suitable for biological removal. The main removal mechanisms in the phosphorus retention are chemical adsorption and precipitation with the soil minerals (Kadlec and Knight, 1996); (Zhang et al., 2014). The range of seconds order constant obtained for the phosphorus removal in all the case (Table 5) is greater to the other substrates, due to the high contents of iron minerals in the red ferralitic soil. Sikdar, (2007) reported second order constant values ranging between of $0.031-0.31(\mathrm{mg} / \mathrm{L})^{-1} \mathrm{~d}^{-1}$ for gravel.

There are significant difference between the phosphorus retention in the standard solution and urban wastewater at two temperatures $(\mathrm{p}<0.05)$. Urban wastewater contains relatively high contents of other anions which may compete with the phosphate for the adsorption sites and hence the efficiency of the adsorption may be reduced. However there are not significant differences between phosphorus retention $(\mathrm{p}<0.05)$ at two temperatures studied; only there are significant differences between the two temperatures for the standard solution in the first hour of the reaction $(\mathrm{p}<0.05)$. 


\section{Sorption isotherm experiments}

Fig. 2 shows the adsorption isotherm, an increase of the adsorption is observed at $35^{\circ} \mathrm{C}$, principally for the more concentrated solutions. This result is agree with Shilton (2006), Huang, (2011), Mezenner, (2009), Jin, (2005) and Herrmann et al., (2014) about the temperature influence in the phosphorus adsorption. Statistically significant differences were observed between the phosphorus adsorption to these temperatures $(\mathrm{p}<0.05)$. Several authors agree that retention of phosphorus in substrates and sediments occurs through endothermic reactions, thus the extent of adsorption increases with increasing temperature. This increase of temperature can increase the kinetic energy of adsorbent particles. Consequently, the collision frequency between adsorbent and adsorbate increases. Also, it may be due to the dimensions of the pores which increase at high temperatures. The greater the size is of the particle pores; smaller is the contribution of intraparticle diffusion resistance.

Statistical fit of the two models described previously was compared by using data of adsorption isotherms. The Langmuir and Freundlich models commonly are fit by transforming the data and performing a linear regression. The increase of adsorption with the increase of temperature was corroborated.

The regression equations for the Langmuir and Freundlich isotherm models and the resulting model parameters are listed in Table 6. The experimental results demonstrated that they fit better to the Freundlich model than the Langmuir model based on the $\mathrm{R}^{2}$ values. Both models are better at higher temperature. Del Bubba et al. (2003) and Sikdar (2007) also found that the Freundlich isotherm model was better fitted for data.

The red ferralitic soil has the Langmuir adsorption capacities $(0.96-1.13 \mathrm{~g} / \mathrm{kg})$ superior to different natural media tested with low mineral content. Drizo et al. (1999) observed in a study of several media that the best medium was Fly ash $(0.86 \mathrm{~g} / \mathrm{kg})$ followed by Shale $(0.65 \mathrm{~g} / \mathrm{kg})$ and Sikdar, (2007) reported $0.0207 \mathrm{~g} / \mathrm{kg}$ for gravel. Arias, (2001) carried out a study with different sand of Dinamarca and obtained a maximum adsorption capacity between $0.27-3.94 \mathrm{~g} / \mathrm{kg}$ in this study, the best adsorption was obtained with the sands that present higher minerals content. Similar results were obtained by Li et al. (2013) for sludge samples of China $(0.15-4.16 \mathrm{~g} / \mathrm{kg})$.

Other studies carried out with substrates that have high content of calcium iron or aluminum, presented betters results. Adam et al., (2007) reported for Shellsand $(9,6 \mathrm{~g} / \mathrm{kg})$ and Filtralite $\mathrm{P}{ }^{\circ}$ $(2.5 \mathrm{~g} / \mathrm{kg}), \mathrm{Xu}$ et al., (2006) observed that furnace slag $(8.89 \mathrm{~g} / \mathrm{kg})$ was the best amongst all the media tested followed by fly ash $(8.81 \mathrm{~g} / \mathrm{kg})$. However, some industrial byproducts had an extremely high phosphorus adsorption capacity; e.g. $444 \mathrm{~g} / \mathrm{kg}$ for blast furnace slag (Sakadevan and Bavor, 1997). Furthermore, light expanded clay aggregates (produced by LECA) tested by Reddy et al., (1999) had highly variable phosphorus adsorption capacities (0.037-2.9 g/kg), depending on the soil of origin. The good results obtained allow the use of red ferralitic soil to improve the phosphorus removal in wastewater, considering that this soil is available in the natural form in different regions of Cuba.

\section{Column experiment}

The adsorption column was operated for approximately 8 day and the results obtained from this study are shown in Table 7. A decrease in the phosphate removal rate was observed during the last period of operation for two columns. This decreased was quicker in the column with a higher flow, about $49 \%$ and $38 \%$ at $200 \mathrm{~h}$ to $0.03 \mathrm{l} / \mathrm{h}$ and $0.06 \mathrm{l} / \mathrm{h}$ respectively. Fig. 3, shows the break point at two flows. As expected, the breaking point in the column that operates at higher flow occurred (32 h) to less time for lower flow column $(56 \mathrm{~h})$. The column that operated at higher flow gets the 
saturation quicker and less phosphorus removal is obtained. Mass balance in both columns obtained phosphorus retention of $0.7 \mathrm{~g} / \mathrm{kg}$.

\section{Sequential extraction}

It was a priori assumed that the phosphorus bond to $\mathrm{Fe}$ and $\mathrm{Al}$ would be the main $\mathrm{P}$ removed, because of the low $\mathrm{pH}$ and high Fe content of red ferralitic soil. The results from the sequential extraction of red ferralitic soil used in the experimental columns justified this hypothesis since the phosphorus bond to $\mathrm{Fe}$ and $\mathrm{Al}$ contributed $95 \%$ of the total $\mathrm{P}$ removal. The result strongly suggests that the phosphorus removal in the columns occur by chemical adsorption or precipitation processes in the red ferralitic soil, forming strong Fe-P bonds. Lyngsie et al. (2014) also obtained the formation of strong $\mathrm{Fe}-\mathrm{P}$ bonds with $\mathrm{Fe}$ oxide-based $\mathrm{CFH}-12$ substrate. Table 8 show the phosphorus extracted in each fraction. The physical adsorption was insignificant in all the case; this experiment corroborated the previous results about the increase of adsorption with the increase of temperature. The total phosphorus extracted in both columns was similar to achieved in mass balance of column $(0.7 \mathrm{~g} / \mathrm{kg})$, but it was smaller than maximum capacity adsorption obtained for Langmuir model $(0.96-1.13 \mathrm{~g} / \mathrm{kg})$.

\section{CONCLUSIONS}

The kinetic modelling studies showed, that the removal of phosphorus mainly occurred by chemical process. The increase of temperature resulted in a corresponding increase in the phosphorus removal. Consequently, the chemical absorption and precipitation are dominant phosphorus removal mechanisms in red ferralitic soil. In addition, the results show a better fit to the Freundlich model. The red ferralitic soil has high a phosphorus sorption capacity $(0.96-1.13$ $\mathrm{g} / \mathrm{kg}$ ) in comparison to other natural substrates used for the phosphorus removal in wastewater. The main bound phosphorus in the soil was with iron or aluminum minerals, confirming to what has previously been discussed. The total phosphorus extraction in the soil using in the columns was $0.7 \mathrm{~g} / \mathrm{kg}$. The red ferralitic soil may be a good option to increase the phosphorus sorption in wastewater treatment, mainly in countries where it is naturally available.

\section{ACKNOWLEGEMENTS}

To the Cooperation Inter Universities Project, (VLIR).

\section{REFERENCE}

1. Adam K., Krogstad T., Vrale L., Sovik A.K., Jenssen P.D. (2007). Phosphorus retention in the filter materials shellsand and Filtralite $\mathrm{P}(\mathrm{R})$ - batch and column experiment with synthetic $\mathrm{P}$ solution and secondary wastewater. Ecological Engineering, 29, 200-208.

2. APHA, AWWA, WEF. (2000). Standard Methods for the Examination of Water and Wastewater, 21 th ed., Washington DC.

3. Arias C., del Bubba M., Brix H. (2001). Phosphorus removal by sands for use as media in subsurface flow constructed reed beds. Water Research, 35(5), 1159-1168.

4. Ayoub G., Koopman B., Pandya N. (2001). Iron and aluminium hydroxyl (oxide) coated filter media for low-concentration phosphorus removal. Water Environment Research, 73, 478485 .

5. Brix H., Arias C.A., Del Bubba M. (2001). Media selection for sustainable phosphorus removal in subsurface flow constructed wetlands. Water Science Technology, 44(11-12), 4754. 
6. De Feo G. (2007). Performance of vegetated and non-vegetated vertical flow reed beds in the treatment of diluted leachate. Journal of Environmental Science and Health, 42 (7), 1013-1020

7. Del Bubba M., Arias C.A., Brix H. (2003). Phosphorus adsorption maximum of sands for use as media in subsurface flow constructed reed beds as measured by the Langmuir isotherm. Water Research, 37(14), 3390-3400.

8. Drizo A., Frost C.A., Grace J., Smith K.A. (1999). Physico-chemical screening of phosphateremoving substrates foruse in constructed wetland systems. Water Research, 33(17), 35953602.

9. Gustafsson J.P., Renman A., Renman G., Poll K. (2008). Phosphate removal by mineral-based sorbents used in filters for small-scale wastewater treatment. Water Research, 42, 189-197.

10. Herrmann I., Nordqvist K., Hedström A., Viklander M. (2014). Effect of temperature on the performance of laboratory-scale phosphorus-removing filter beds in on-site wastewater treatment. Chemosphere, 117, 360-366.

11. Hieltjes A. H. M. and Lijklema L. (1980). Fractionation of inorganic phosphates in calcareous sediments. Journal Environmental Quality, 9, 405-407.

12. Huang L. D., Fu L. L., Jin C. W., Gielen G., Lin X. Y., Wang H. L. and Zhang Y. S. (2011). Effect of temperature on phosphorus sorption to sediments from shallow eutrophic lakes. Ecological Engineering, 37, 1515-1522.

13. Kadlec R. H., Knight L. (1996). Treatment Wetlands, Lewis Publishers, Boca Raton, FL.

14. Klimeski A., Chardon W. J., Turtola E., Uusitalo R. (2012). Potential and limitations of phosphate retention media on water protection: A process-based review of laboratory and fi eld-scale tests. Agricultural and Food Science, 21 206-223.

15. Jin X., Wang S., Pang Y., Zhao H. and Zhou X. (2005). The adsorption of phosphate on different trophic lake sediments. Colloids and Surfaces A: Physicochemical Engineering Aspects, 254 241-248.

16. Klute A. (1986). Methods of soil analysis. Part I: Physical and mineralogical methods $2^{\text {nd }}$ edt. American Society of Agronomy, Madison, WI, USA.

17. Laak R. (1986) Wastewater Engineering Design for Unsewered Areas. Technomic Publishing, The Hague, The Netherlands.

18. Li Z., Jiang N., Wu F., Zhou Z. (2013). Experimental investigation of phosphorus adsorption capacity of the waterworks sludges from five cities in China. Ecological Engineering, 53, $165-172$.

19. Lyngsie G., Penn C. J., Hansen C.B., Borggaard K. (2014). Phosphate sorption by three potential filter materials as assessed by isothermal titration calorimetry. Journal of Environmental Management, 143, 1-214.

20. Metcalf and Eddy (2003) Wastewater Engineering: Treatment and Reuse, 4th edn., McGraw Hill, New York.

21. Mezenner N. Y. and Bensmaili A. (2009). Kinetics and thermodynamic study of phosphate adsorption on iron hydroxide-eggshell waste. Chemical Engineering Journal, 147, 87-96.

22. Pérez M. M., Rosa E., Martínez P., López M. E., González Y., Monteagudo M. (2009). Evaluación de la eficiencia de diferentes sustratos de filtros de suelo plantados en la depuración de aguas residuales domésticas (Evaluation of efficiency of planted soil filter substrates in domestic wastewater depuration). CENIC Ciencias Biológicas, 40, 99-103.

23. Reddy, K.R., Kadlec, R.H., Flaig, E. and Gale, P.M. (1999). Phosphorus Retention in Streams and Wetlands: A Review. Environmental Science Technology, 29 (1), 83-146.

24. Sakadevan, K. and Bavor, H.J. (1997). Phosphate Adsorption Characteristics of Soils, Slags and Zeolite to be used as Substrates in Constructed Wetland Systems. Water Research, 32 (2), 393-399. 
25. Shilton A.N., Elmetri I., Drizo A., Pratt S., Haverkamp R.G., Bilby S.C. (2006). Phosphorus removal by an active slag filter: a decade a full scale experience. Water Research, 40(1), 113118.

26. Sikdar A. (2007). Quantification of complex phosphorus removal reactions occurring within wetlands filtration treatment systems Doctor of philosophy thesis, Department of Civil Engineering, Queen's University, Kingston, Ontario, Canada.

27. Van ranst E., Verloo M., Demeyer A., Pauwels J.M. (2005). Analytical methods for soil and plants equipment and management of consumables. Manual for the soil chemistry and fertility laboratory.

28. Vohlaa C., Kõiva M., Bavorb J.H., Chazarencc F., Mandera Ü. (2011). Filter materials for phosphorus removal from wastewater in treatment wetlands-A review. Ecological Engineering, 37, 70-89.

29. Xu D., Xu J., Wu J., Muhammad A. (2006). Studies on the phosphorus sorption capacity of substrates used in constructed wetland systems. Chemosphere, 63, 344-352.

30. Liu J., Zhou Q., Luo J., Zhang J., Wang X. (2014). Removal of phosphate from water using raw and activated laterite: batch and column studies. Desalination and Water Treatment, 52 (46), 778-783.

31. Zhu T., Mæhlum T., Jenssen P.D., Krogstad T. (2003). Phosphorus sorption characteristics of light-weight aggregate. Water Science and Technology, 48, 93-100. 